\title{
The Gender Wage Gap in Early Modern Toledo, 1550-1650*
}

\author{
Mauricio Drelichman \\ The University of British Columbia \\ and CIFAR \\ 6000 Iona Drive \\ Vancouver BC V6T 2G2 Canada \\ mauricio.drelichman@ubc.ca
}

\author{
David González Agudo \\ The University of British Columbia \\ 6000 Iona Drive \\ Vancouver BC V6T 2G2 Canada \\ dagoag@mail.ubc.ca
}

First draft: February 5, 2019

This version: April 2, 2019

\begin{abstract}
We exploit the records of a large Toledan hospital to study the compensation of female labor and the gender wage gap in early modern Castile in the context of nursing, a non-gendered low-skill occupation in which men and women performed the same clearly defined tasks. We employ a robust methodology to valuate in-kind compensation, and show it to constitute a central part of the labor contract, far exceeding subsistence requirements. Patient admissions records are used to measure nurse productivity, which did not differ across genders. Female compensation varied between $70 \%$ and $100 \%$ of male levels, with fluctuations clearly linked to relative labor scarcity. Contrary to common assumptions in the literature, we show that female compensation in early modern Castile was set through a competitive market, and not according to custom. The sources of the gender disparity are therefore likely to be found in the broader social and cultural context.
\end{abstract}

JEL classification: N33, N93, J16

\footnotetext{
* For helpful discussions we thank Libertad González, David Green, Jane Humphries, Ernesto López Losa, Hugo Ñopo, Marit Rehavi, Carmen Sarasúa, and seminar participants at CEMFI. We gratefully acknowledge the assistance of Patxi Guerrero Carot at the Ducal Archive of Medinaceli, as well as the support of Fundación Casa Ducal de Medinaceli. Drelichman acknowledges financial support from SSHRC through Insight Grant 435-20150285, and the hospitality of CEMFI through the María de Maeztu visitor program during the fall of 2018 . All errors are ours.
} 


\section{Introduction}

The role of women in labor markets, and the determination of female salaries in particular, is the subject of a vast and growing literature. In recent times women have broken into occupations traditionally reserved for men and have made substantial progress in reducing salary gaps, at least in the developed world. ${ }^{1}$ These advances highlight the stark differences in the occupational domain, skills, and earnings potential between genders in virtually every country and historical period before the $20^{\text {th }}$ century. The study of such differences, and their variation across time and space, is crucial to understanding the functioning of labor markets and the role of women in society through history.

Female wage records are widely available from the onset of industrialization on, and numerous studies have examined the magnitude of women's earnings, their determinants, their relationship with male compensation, and their implications for female living standards. ${ }^{2}$ The primary sources, however, quickly thin out as we delve further back into the past, to the point that data on early modern female wages is notoriously scarce. Even when available, several problems hinder their use in constructing series comparable to those for male workers, and hence identifying differences in wage-setting practices and the source of gender gaps. ${ }^{3}$ Women were often compensated as part of teams, or their employment was accessory to their husbands'. When paid

\footnotetext{
${ }^{1}$ See Olivetti and Petrongolo (2016) for a survey of the literature on gender gaps in industrialized countries, and Goldin (2014) for a recent discussion of gender convergence in labour markets. Blau et. al. (2014) is a comprehensive methodological and data reference for labour gender issues. Goldin (1990) is the classic treatment at the intersection of the labour and economic history literatures.

${ }^{2}$ For an exhaustive analysis of female work, wages, and gender gaps in Industrial Revolution Britain, see Burnette (2008). For women's labor force participation across $19^{\text {th }}$ century Europe, see Humphries and Sarasúa (2012). The longest series of female wages is the one compiled by Humphries and Wesidorf (2015) for Britain between 1260 and 1850. Female living standards at the time of industrialization are discussed by Nicholas and Oxley (1993) and Horrell and Oxley (2012).

${ }^{3}$ For a thorough discussion of the difficulties of working with wage data in the context of pre-modern Britain, see Humphries and Weisdorf (2015, pp. 407-411).
} 
a daily wage, it is often impossible to establish whether they worked the same number of days, or hours per day, as men -and quite frequently it is clear they did not. ${ }^{4}$ Even when their job title was the same as that of male workers, women often did not perform the same tasks. In addition, when employed for an annual wage, a large part of their compensation (and sometimes all of it) could be in kind, further complicating the calculation of total earnings.

The lack of data on female labor is particularly acute for early modern Spain. The comparative literature has relied on scant published series of daily wages from construction records, largely collected by Earl Hamilton more than eight decades ago. These studies suggest that, in the late medieval and early modern periods, Spanish women were paid about $50 \%$ of male wages, a level that is seen to be dictated by custom rather than by market forces. ${ }^{5}$ As we argue in more detail below, construction was a very marginal activity for Castilian women, and the tasks assigned to them were not comparable to those carried out by men. Similar ideas about the "customary" nature of women's labor market participation in other periods of Spanish history have been proven wrong when comprehensive data sources have been brought to bear on the issue. Work on the basis of the 1750s Catastro de Ensenada, for example, has shown that women's labor market participation was much higher than previously assumed, shattering stereotypes of a largely inactive female population. ${ }^{6}$ The use of thin, decades old data from the construction sector is not a good omen for the robustness of pre-eighteenth century female wage estimates.

We exploit the payroll, storehouse, purchasing, and admissions records of a large Toledan hospital to identify the gender wage gap between contemporary male and female nurses from 1553 to 1650 . Nursing was a non-gendered occupation, as hospitals required that patients be

\footnotetext{
${ }^{4}$ Burnette (1997, p. 263).

${ }^{5}$ De Pleijt and Van Zanden (2018).

${ }^{6}$ Humpries and Sarasúa (2012, p. 53).
} 
assisted exclusively by nurses of their same gender. We present detailed information on both cash and in-kind compensation, and recover the necessary data to accurately valuate the latter, both at cost of acquisition and at market prices. We also use data on the ratio of nurses to patients to show that productivity levels differed little by gender. We find that female compensation fluctuated between $70 \%$ and $100 \%$ of male levels, and that the hospital responded swiftly to labor scarcity or abundance when setting wages.

Our analysis has two main limitations: it relies on a single source, and it covers a single occupation. This reflects the nature of primary sources from the early modern period, for which the combination of a long payroll series, accurate information on in-kind payments, and nongendered occupations in which men and women performed the exact same tasks is an extremely rare find. In exchange, it arguably offers the cleanest possible setting to study the gender wage gap in pre-industrial times. Their circumscribed nature notwithstanding, our results are a pointed counterexample to some common assumptions regarding female work and compensation in Southern Europe during this period. With our evidence pointing to substantially smaller and far more variable gender gaps than those implied by problematic construction day wages, it appears necessary to re-evaluate the use of the latter in cross-country studies, as well as to qualify any associated conclusions on Southern European female labor patterns. Our work also contributes to the current debate on the measurement of real wages in pre-modern times, with a particular focus on the nature of in-kind compensation. ${ }^{7}$ Contrary to current assumptions in the literature, we show that payments in kind far exceeded subsistence requirements, and played an important role in shielding workers' earnings from inflation.

\footnotetext{
${ }^{7}$ For a comprehensive overview of the issues surrounding pre-modern real wages, see Hatcher and Stephenson (2018) and the contributions therein.
} 


\section{Historical context}

In the mid sixteenth century, Toledo had a population of around 47,000, inhabitants, second only to Seville among Castilian cities. ${ }^{8}$ Located almost at the geographical center of the Iberian peninsula, it had been a key crossroads since pre-Roman times. It hosted the Primatial See of Spain, and was the richest diocese in Christendom after Rome. ${ }^{9}$ It benefited from a fertile countryside, an important trade in textiles, a famous iron and leather manufacturing industry, and the large economic stimulus provided by the frequent presence of the king and his entourage. ${ }^{10}$ The permanent establishment of the capital in Madrid in 1561 would deal a substantial blow to the long-term fortunes of the city. ${ }^{11}$ However, for the remainder of the sixteenth century, Toledo remained a vibrant center for trade, industry, and the arts. Large construction projects continued apace, and a number of charitable institutions opened their doors during this time. In the last decade of the sixteenth century, a series of plagues, famines, and ill-considered municipal policies started a process of depopulation that would, in time, prove irreversible. By 1645, the population of the city had fallen by half relative to its sixteenth-century peak. ${ }^{12}$

\section{a) Construction workers}

Construction wages have long been the focus of regional, national, and comparative studies of labor compensation. ${ }^{13}$ The sources are relatively plentiful, construction projects tend to last for a

\footnotetext{
${ }^{8}$ The 1571 census showed 12,412 households in the city (Martz, 1983, p. 93). We convert them to inhabitants using a coefficient of 3.78 persons per household, following estimates by Carasa Soto (1983) for the area around Madrid (3.78), by Martín Galán (1985) for the province of Guadalajara (3.78), by López-Salazar Pérez (1976) for the region of La Mancha (3.78), and by Sánchez Sánchez (1981) for the Toledan parish of Santiago del Arrabal (3.7).

${ }^{9}$ Villaluenga de Gracia (2005).

${ }^{10}$ Martz (1983); Carrobles Santos et al. (1997).

${ }^{11}$ For a comprehensive analysis of the impact of Madrid's selection as the monarchy's capital on Toledo's fortunes, see Ringrose (1973).

${ }^{12}$ Martz (1983) and Montemayor (1995) compile Toledan population histories through the use of censuses and baptismal records.

13 Allen (2001), the seminal study on internationally comparable living standards in the long run, is based on mason wages. Van Zanden (2009) expands the analysis to the study of the skill premium (and adds a number of non-
} 
long time, and it is relatively simple to identify skill categories, at least within comfortable periods and geographical areas. Naturally, scholars have sought to tap into the same sources to study female wages. De Pleijt and van Zanden (2018), who attempt to build a long-run series of the gender wage gap in Spain in order to compare it with those of other countries, rely exclusively on published data for male and female construction workers. ${ }^{14}$ They find that, for the late medieval period, women in Northern Spain were paid $50 \%$ of male wages, a point also echoed by Lanza García (2008, p. 4) for Cantabria in the early modern period. We initially approached our research using construction records, but quickly discovered them to be an extremely problematic source to study female work, at least in Spain. ${ }^{15}$

The first problem is that female construction workers were unlikely to perform the same tasks as men. In the daily wage payments collected by Orcástegui Gros (1985) for Zaragoza around the year 1300 , for example, women that worked in construction sites were always said to have "helped" with various activities, a term also used for child workers. The most common of these tasks was amasar-mix the plaster to be applied in interior finishing and decorations- which required little physical effort. Their daily wages match exactly the "norm" of 50\% of male wages identified by de Pleijt and van Zanden, but their activities were clearly not comparable to those of men working at the same site. Even in those cases where women performed hard physical labor, such as the instances documented by Humphries and Weisdorf (2015, p. 409), differences

European countries) using the differential between the wages of different categories of construction workers. Rota and Weisdorf (2019) argue that daily construction wages are higher than those of other unskilled occupations to compensate workers for the seasonality and volatility of construction work.

${ }^{14}$ Humphries and Weisdorf (2015) use construction day wages for women in their series. However, they are able to identify the specific tasks carried out by women (carrying stones, supplying muscle power for cranes). They also source the majority of their data from annual contracts in sectors other than construction. Gary (2017) also relies on female construction workers from Southern Sweden.

${ }^{15}$ Relatedly, Stephenson (2018) shows that, from the mid-seventeenth century on, the inference of daily London construction wages from labor contracts overlooks embedded intermediary fees, thus inflating the results. This does not appear to be an issue in medieval and early modern Spain, where workers were paid individually. 
in physical strength between the genders raise questions of productivity, precluding the identification of the various components of the wage gap.

More crucially, construction work seems to have been a very marginal source of employment for Castilian women. For a related project, we have sampled the daily wage payments at the construction works of Tavera's hospital, then one of the largest construction sites in Toledo, between 1552 and 1637 , at a bi-weekly frequency. ${ }^{16}$ Of the 23,073 individual daily payments in that database, only 27 were issued to women, all of them in the peón (unskilled laborer) category. ${ }^{17}$ Women's daily wages varied between $50 \%$ and $75 \%$ of those of the male laborers that worked on the site on the same dates, with an average ratio of $63 \%$. Although our sample covers 85 years, women appear in it only during the boom period between 1573 and 1578, and then exclusively on days when there were very few men on site. ${ }^{18}$ Taken together, the very low prevalence of women in Castilian construction sites and the different tasks they were assigned relative to men strongly advise against using construction wages as the basis for studying the overall female labor market participation or the gender pay gap.

\section{b) The nurses of Tavera's hospital}

Controlling for employer, task, worker characteristics, and productivity is key to identifying the various components of gender wage gaps. The standard tools of analysis are decomposition techniques, which require modern firm and worker-level data. The nature of historical sources, however, means that precise identification is only possible in the context of a very close

\footnotetext{
${ }^{16}$ Archivo Ducal de Medinaceli, Hospital de San Juan Bautista (Tavera), Copias de obra.

${ }^{17}$ A similar effort in the archives of the Cathedral Works, as well as the construction records of other Toledan hospitals, yielded an even lower rate of female workers.

${ }^{18}$ This is in line with Gary (2017), who shows that women's participation in construction work in Southern Sweden increased sharply during boom periods. However, women accounted for between $30 \%$ and $60 \%$ of Gary's sample, while they only represent a very small fraction of ours.
} 
matching exercise, with male and female workers performing the exact same task, one at which both genders were equally productive. There are precious few such examples and, to our knowledge, none providing comprehensive annual earnings for the period before $1650 .{ }^{19}$ Many occupations were strongly segregated by gender; even when there was a reasonable gender split, it is often difficult to establish whether men and women performed the same tasks, worked the same number of hours per day, or days per year.

The payroll records of the Hospital of San Juan Bautista (better known as Tavera's Hospital after its founder, Cardinal Juan Pardo de Tavera) offer an ideal setting to address the issues of selection and comparability that normally affect attempts to decompose gender gaps. Founded in 1541, and operational from 1553, the hospital's chief mission was to tend to poor people affected by acute, non-contagious diseases ${ }^{20}$ In order to fulfill it, it admitted patients into gendersegregated wards with a comprehensive capacity of about 100 beds. ${ }^{21}$ The medical staff consisted of a chief physician, a surgeon, and a barber/bleeder, who assessed the medical condition of the patients and performed procedures. The nursing staff was under the direction of a (male) head nurse, whose responsibilities were largely administrative and spiritual. He was to accompany the physician on his rounds, keep abreast of the status of each patient, and ensure that the sick received the prescribed sacraments, especially if they were in danger of dying. ${ }^{22}$ The day-to-day care of the sick, which included serving their meals, administering medicines, and

\footnotetext{
${ }^{19}$ Van Nederveen Meerkerk (2010) is perhaps the cleanest such study, focusing on piece rates paid to male and female spinners in the Low Countries. While she offers a handful of observations dating back as early as 1600, the data that allows to perform comparisons between the genders are all from the post-1650 period. Gary (2017) provides a fairly continuous series of Swedish daily female wages from 1600 on, as well as several scattered observations dating back to the mid- $16^{\text {th }}$ century.

${ }^{20}$ People affected by contagious diseases were segregated at specific hospitals, while those with chronic conditions were received in hospices. An exception to this rule was made during episodes of pestilence, when all hospitals in the city had to receive plague patients (Zamorano Rodríguez, 1997, p. 25).

${ }^{21}$ Zamorano Rodríguez (1997, p. 27).

${ }^{22}$ See the appendix for a discussion of the role of the head nurse.
} 
assisting with their hygiene, was the responsibility of the regular nurses. The bylaws specified that only nurses of the same gender as the patients were allowed to care for them. ${ }^{23}$ Nurses of both genders lived at the hospital, and were not allowed to leave the premises at any time, likely restricting the position to either unmarried or widowed men and women. ${ }^{24}$

\section{Compensation}

In order to calculate the total compensation of the nursing staff for a period of almost 100 years, we collected data on both monetary wages and food rations. In addition, we obtained a new, direct measure of the cost of bread, and relied on published sources and our own previous work to valuate the remaining food items, as well and lodging. The result is a direct, precise estimate of annual earnings, and one of the first such exercises for any pre-modern wage series.

\section{a) Monetary wages}

The main source for monetary wages are the payroll records, which are available with few gaps between the hospital's inception and $1650 .{ }^{25}$ Payroll accounting and payout was conducted three times a year, at the end of April, August, and December. We collected the names and annual cash wage rates of the nurses listed on the August payroll lists each year when available, using the April or the December ones as backups. ${ }^{26}$ Between 1575 and 1624 the payroll records list no female nurses. We traced their wage payments to the hospital's regular account books, from

\footnotetext{
${ }^{23}$ Zamorano Rodríguez (1997, pp. 121-122, 128-129).

${ }^{24}$ Zamorano Rodríguez (1997, p. 27).

${ }^{25}$ Archivo Ducal de Medinaceli, Hospital de San Juan Bautista (Tavera), Nóminas. While the payroll records continue after 1650 , the data needed to valuate in-kind compensation does not, thus dictating the end date of our exercise.

${ }^{26}$ The records list both the annual wages and the amounts actually paid out that term (which is usually one third of the annual rate, unless employment was initiated or terminated in that period, or a worker took sick leave).
} 
where we obtained their names and annual wage rates as well. ${ }^{27} \mathrm{We}$ also recorded the names and wages of the head nurses, and those of a few nurse helpers (always female). In total, our database contains 728 individual entries, of which 414 correspond to male nurses, 217 to female nurses, 89 to (male) head nurses, and the remaining 8 to nurse helpers.

In any given year, all regular nurses of each gender were paid the same nominal wage rate.

Changes in these rates were rare, and so the data are easily described. The Castilian monetary unit was the maravedi. The head nurse earned 7,000 maravedis (mrs.) in 1553, and 12,000 mrs. every year thereafter (with the exception of the single year of 1631, when he was paid 10,000 mrs.). Regular male nurses earned 4,000 mrs. per year between 1553 and 1566, and 5,000 mrs. per year thereafter. Female nurses cash wages started out on par with those of male nurses. They were set at 4,000 mrs. per year between 1553 and 1574, dropping to 3,264 mrs. per year between 1575 and 1596 . They were increased to $4,080 \mathrm{mrs}$. between 1598 and 1611 , and further raised to 4,896 mrs. in $1612 .^{28}$

\footnotetext{
${ }^{27}$ Archivo Ducal de Medinaceli, Hospital de San Juan Bautista (Tavera), Gasto ordinario y extraordinario. The reason for the switch is unclear. Other employees also occasionally switch between the payroll records and the regular account books.

${ }^{28}$ While some gaps in both the payroll and ordinary account books' series exist, the infrequent changes in wage rates mean that it is possible to fill them in with virtual certainty. The only documentary gap that coincides with a wage rate change is the missing account book for 1597 -we observe female nurses being paid 3,264 mrs. in 1596 and 4,080 mrs. in 1598. Rather than interpolate the 1597 value (which would almost certainly be incorrect), we have entered a missing value.
} 
Figure 1: Cash wages (in 1551-1560 constant maravedis)

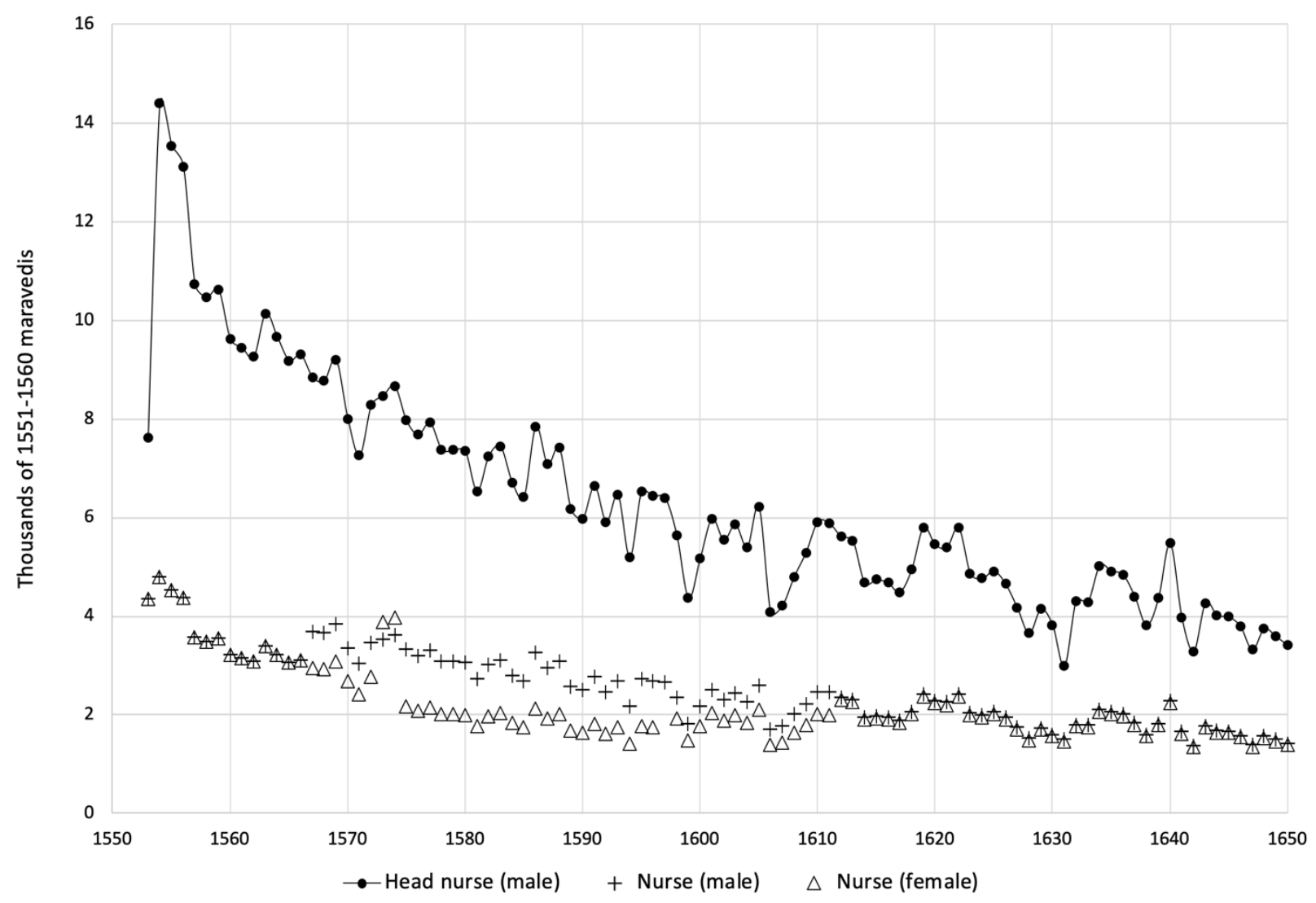

Figure 1 shows the evolution of the monetary component of wages, deflated by the Toledo price index from González Agudo (2019). Between 1550 and 1650 the purchasing power of cash wages fell by more than two thirds (three quarters in the case of the head nurse) as a result of the price revolution and, starting in 1603, the issuance of copper coinage. The jagged profile of the series reflects the jumpiness of the consumer price index, itself the result of the large year-toyear variation in the price of key staples. This made the in-kind components of workers' pay especially valuable, as they provided insurance against fluctuations in the price of basic foodstuffs.

\section{b) In-kind compensation}

In addition to their monetary wages, nurses received food and lodging. Since the design of the wards did not differ by gender, we assign equal value to the lodging of both men and women, 
using the annual rental cost of the average living space in a poor neighborhood in Toledo. ${ }^{29}$ The imputed value of rent averages $4.5 \%$ of the total compensation of female nurses, peaking at $6.8 \%$ in 1595 and reaching a nadir of $1.7 \%$ at the very end of the period, when the Toledo rental market was in freefall because of sustained emigration. ${ }^{30}$ Since the monetary amounts imputed are the same for men and women, they have no bearing on the level of the wage gap, and little impact on its relative magnitude. To valuate the lodging cost of the head nurse, we relied on a housing allowance given to the pharmacist, an employee of similar rank, in 1600 and 1601 . The amount $-4,500$ mrs. per year- was equivalent to the rental cost of a 32 square metre apartment in an upmarket neighborhood. We therefore imputed the cost of similar lodgings during the entire period as part of the head nurses' in-kind bundle.

Food, either served at meals or handed out as rations, accounted for the largest share of total compensation. Meals and rations for rank and file employees consisted almost exclusively of bread, wine, and mutton - any additional items had to be purchased separately. ${ }^{31}$ The head nurse had the privilege of sitting at the chaplains' table, where starters (including various vegetables and soups) and dessert were also served.

Two different offices managed food and meals. The botillería was in charge of purchasing all types of foodstuffs, as well as of arranging the bread supplies. Acquisitions were transferred to the despensa, or storehouse, which was responsible for supplying the kitchen and keeping track

\footnotetext{
${ }^{29}$ In Drelichman and González Agudo (2014) we calculate that the average working class dweller of Toledo rented approximately 15 square metres of space, and provide annual estimates of the rental cost per square metre in both rich and poor neighborhoods between 1489 and 1650 .

${ }^{30}$ Allen $(2001,2013)$ started the widely echoed practice of imputing rental expenditures as a 5\% mark-up on all other expenses. We showed that, for Toledo dwellers between 1489 and 1650 , rent accounted for $9.5 \%$ of subsistence incomes on average (Drelichman \& González Agudo, 2014). Tavera's nurses earnings were substantially above subsistence, so the cost of a working class dwelling represented a commensurately lower share of their budgets.

${ }^{31}$ Patients were offered a much more varied diet; since nurses often took their meals in the wards, it wouldn't be surprising if they had managed to add some variety to their diet from leftover patient meals.
} 
of the meals given to patients, the rations served or handed out to employees and, in some cases, cash allowances given in lieu of rations. Accounting for the various items served or handed out was shared between the two offices, with their responsibilities varying throughout the period. Properly valuating meals and rations requires collecting and cross-validating a substantial amount of data from both botilleria and despensa books, which are available in largely complete series. ${ }^{32} \mathrm{~A}$ full description of the methodology is given in the appendix.

Bread, the most important staple in early modern diets, deserves special attention. The scarcity of early modern bread prices has prompted scholars to come up with workarounds and innovative solutions, including the use of a rule of thumb on the basis of wheat prices (López Losa \& Piquero Zaráuz, 2018), and Allen's (2001) regression and retrocasting approach. Our sources offer a direct measure of the wholesale price of bread, which can be obtained at annual (or higher) frequency. We can also identify and account for the impact of changes in local taxation at different stages of the production process, which is not possible when relying on estimates based on wheat prices. Our series of bread prices is the earliest available direct measure for Castile, and joins just a handful of others predating 1600 in Europe. ${ }^{33}$ The appendix describes the sources and methodology in full.

As in the case of monetary wages, in-kind compensation bundles experienced few changes throughout the period. Between 1553 and 1626 the daily ration of male nurses consisted of 2.5 pounds of bread, one pound of mutton, and 1.025 litres of wine (half an azumbre). In 1627, the

\footnotetext{
${ }^{32}$ Archivo Ducal de Medinaceli, Hospital de San Juan Bautista (Tavera), Libros de botillería and Libros de despensa. The botillería books were a major source of price data for Earl Hamilton's (1934) classic work on the price revolution.

${ }_{33}$ Sixteenth century bread price data from direct measures include Van Zanden's (2001) rye bread series for the Western Netherlands, Pamuk's (2001) data for Istanbul, and Gibson and Smout's (1995) for Scotland. Feliú (1991) offers comparable data to ours for Barcelona starting in 1533.
} 
bread ration was reduced to 2 pounds per day. Female nurses were initially issued the same ration as their male counterparts. In 1573, the single female nurse on staff negotiated an increase of 1,500 mrs. in her cash compensation in exchange for reducing her wine ration in half. Her departure, two years later, marked a drastic reduction in the compensation of female nurses. Not only was the original wine ration not restored, but the bread ration of her successors was cut to two pounds per day. Female nurses stopped eating their meals in the refectory, which led to them being issued a cash allowance instead of cooked mutton. Despite occasional adjustments, this amount tended to lag behind the actual value of the meat. In 1637, mutton rations for female nurses were restored.

Head nurse rations were more variable, as they included a share of the food served at the chaplain's table. In general they contained an extra half pound of mutton relative to the regular male nurses' rations and, in the seventeenth century, somewhat less bread. Head nurses also benefited from a variety of prepared dishes, vegetables, and desserts, which the storehouse books do not itemize but for which they provide a monetary value (see the appendix for more details on this point).

Table 1 lists the initial cash wages and food rations given in 1553 to all three types of employees, as well as their changes throughout the following century. While the quantities of food given as rations changed on only a handful of occasions, it is worth noting that cash allowances in lieu of food, as the offerings of at the chaplains' table, varied constantly. Fully accounting for the value of in-kind compensation, therefore, still required frequent sampling from the relevant sources. 
Table 1: Cash and in-kind compensation summary

Panel A: Initial compensation levels (1553)

\begin{tabular}{|c|c|c|c|c|c|c|}
\hline & \multicolumn{2}{|c|}{ Male nurses } & \multicolumn{2}{|c|}{ Female nurses } & \multicolumn{2}{|c|}{ Head nurse } \\
\hline Year & Cash (per year) & In kind (per day) & Cash (per year) & In kind (per day) & Cash (per year) & \begin{tabular}{|l} 
In kind (per day) \\
\end{tabular} \\
\hline 1553 & 4,000 mrs. & $\begin{array}{l}\text { Bread: } 2.5 \mathrm{lbs} . \\
\text { Mutton: } 1 \mathrm{lb} . \\
\text { Wine: } 0.5 \mathrm{az} .\end{array}$ & 4,000 mrs. & $\begin{array}{l}\text { Bread: } 2.5 \mathrm{lbs} . \\
\text { Mutton: } 1 \mathrm{lb} . \\
\text { Wine: } 0.5 \mathrm{az} .\end{array}$ & 7,000 mrs. & \begin{tabular}{|c} 
Bread: 2.5 lbs. \\
Wine, mutton, starters and \\
dessert as a share of the \\
chaplain's table (value \\
varies daily).
\end{tabular} \\
\hline
\end{tabular}

Panel B: Changes in compensation levels

\begin{tabular}{|c|c|c|c|c|c|c|}
\hline \multirow[b]{2}{*}{ Year } & \multicolumn{2}{|c|}{ Male nurses } & \multicolumn{2}{|c|}{ Female nurses } & \multicolumn{2}{|c|}{ Head nurse } \\
\hline & Cash (per year) & In kind (per day) & Cash (per year) & In kind (per day) & Cash (per year) & In kind (per day) \\
\hline 1554 & & & & & $\begin{array}{c}\text { Increase to } 12,000 \mathrm{mrs} \text {. } \\
\text { per year }\end{array}$ & \\
\hline 1567 & $\begin{array}{c}\text { Increase to } 5,000 \mathrm{mrs} \text {. per } \\
\text { year }\end{array}$ & & & & & \\
\hline 1573 & & & $\begin{array}{c}\text { Increase to } 5,500 \mathrm{mrs} \text {. per } \\
\text { year }\end{array}$ & $\begin{array}{l}\text { Wine reduced to } 0.25 \text { az. } \\
\text { per day }\end{array}$ & & \\
\hline 1575 & & & $\begin{array}{c}\text { Decrease to } 3,264 \text { mrs. per } \\
\text { year }\end{array}$ & $\begin{array}{c}\text { Bread reduced to } 2 \mathrm{lbs} \text {. per } \\
\text { day. Cash allowance } \\
\text { introduced in lieu of } \\
\text { mutton ration. }\end{array}$ & & \\
\hline 1598 & & & $\begin{array}{c}\text { Increase to } 4,080 \mathrm{mrs} \text {. per } \\
\text { year }\end{array}$ & & & \\
\hline 1612 & & & $\begin{array}{c}\text { Increase to } 4,896 \text { mrs. per } \\
\text { year }\end{array}$ & & & \\
\hline 1627 & & $\begin{array}{l}\text { Bread reduced to } 2 \mathrm{lbs} \text {. per } \\
\text { day }\end{array}$ & & & & $\begin{array}{c}\text { Bread, wine, and mutton } \\
\text { daily rations fixed at } 1.75 \\
\text { lbs., } 0.5 \text { az., and } 1.5 \mathrm{lbs} . \\
\text { respectively. }\end{array}$ \\
\hline 1631 & & & & & $\begin{array}{c}10,000 \text { mrs. for this year } \\
\text { only. }\end{array}$ & \\
\hline 1637 & & & & $\begin{array}{c}\text { Mutton ration }(1 \mathrm{lb} \text {. per } \\
\text { day) replaces the cash } \\
\text { allowance introduced in } \\
1575 .\end{array}$ & & \\
\hline
\end{tabular}

Source: Archivo Ducal de Medinaceli, Hospital de San Juan Bautista (Tavera), Nóminas, Libros de Gasto, Libros de Botillería, Libros de Despensa (1553-1650)

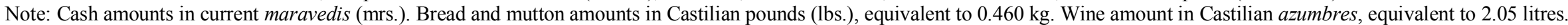


To obtain a comprehensive monetary equivalent for in-kind compensation, we first need to select suitable price series. For mutton we have only one option, Hamilton's (1934) prices, which were sourced from Tavera's botillería books and therefore reflect the hospital's acquisition cost. Our new series of bread prices also reflects the hospital's acquisition cost, while Allen's (2001) estimates are probably closer to retail prices until 1618 . For wine, we similarly have a choice between Hamilton's series as a cost indicator, or González Agudo's (2019) data from City Hall as an estimate of retail prices. We can therefore valuate the in-kind bundles at what it cost the hospital to buy them, or at something closer to what a regular person would have paid for them on the street. The latter poses two problems. First, as discussed in the appendix, Allen's methodology for estimating bread prices does not do a good job of accounting for structural breaks, at least one of which is present in our period. Second, employees probably could not have sold their surpluses of bread, wine, or mutton at retail prices, and might well have chosen to purchase different bundles if they had been compensated in cash. These issues may lead to overestimating the value of in-kind compensation if retail prices are used. To err on the side of caution, and to use consistent, high-quality data, we rely on cost-of-acquisition as our preferred price measure. In the appendix, we discuss the results obtained using "retail" prices for robustness. 
Figure 2: Value of in-kind compensation, at cost of acquisition

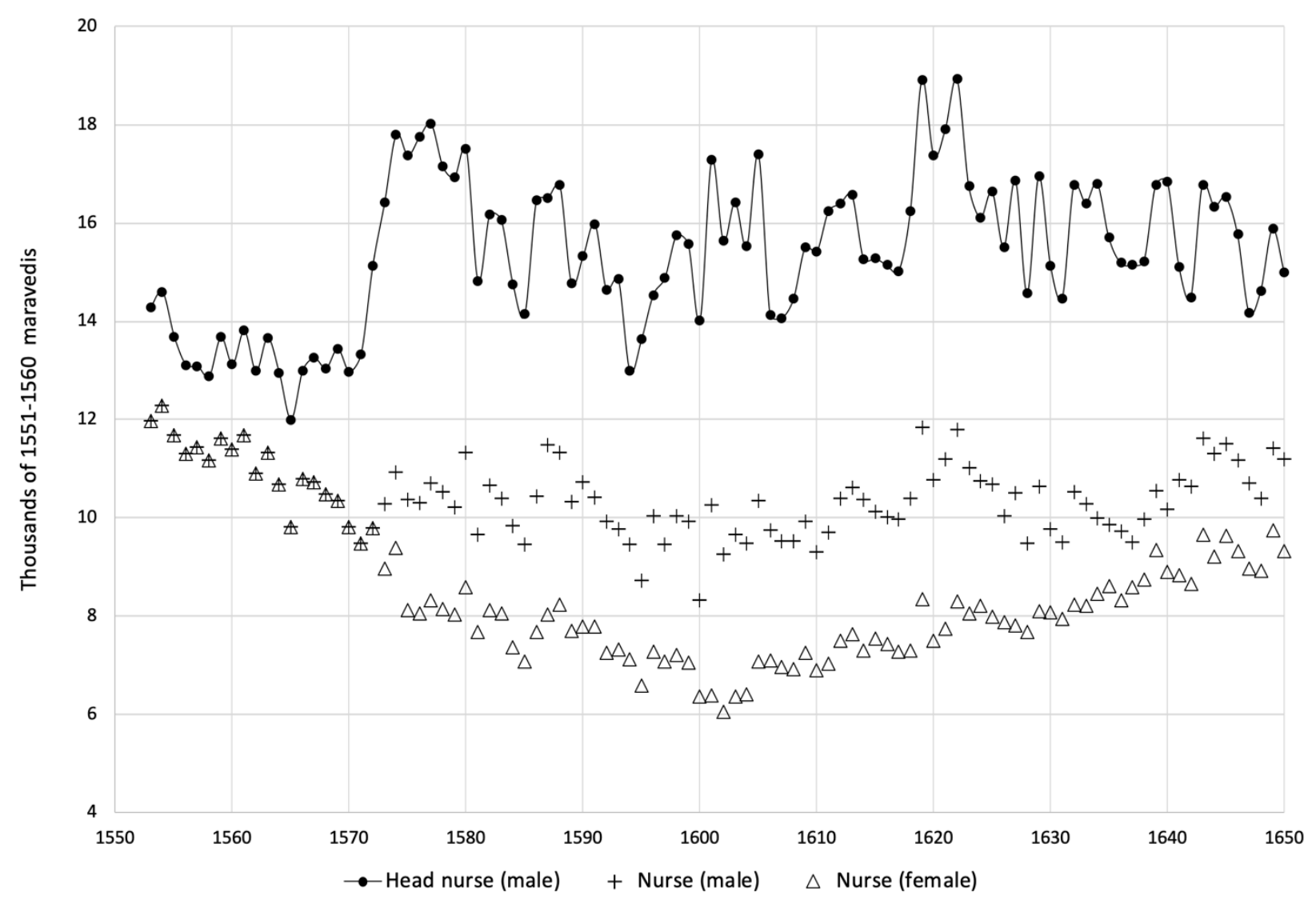

Figure 2 shows the value of in-kind compensation for the three types of employees, in real terms, at cost of acquisition. At the start of hospital operations their bundles were very similar, with the valuation for the head nurse reflecting the higher value of lodging. In the early 1570 s, the head nurse's compensation increased substantially, largely as a result of improvements in the chaplain's dinner and on more generous wine rations. At the same time, the reduction in the amounts of wine and bread given to female nurses, as well as the switch to a cash allowance in lieu of mutton (still added to the in-kind compensation for comparability), opened up a substantial gap between male and female nurses. The gap increased until 1601, when female nurses in-kind compensation was worth only $62 \%$ of the one received by their male counterparts. By 1606 , progressive increases in the cash allowance of female nurses started to reduce the difference. The $20 \%$ cut in the bread allowance of male nurses in 1627 and the reinstatement of 
mutton rations for females in 1637 brought the gap to its lowest value since the 1570 s, with the only remaining difference being half a litre of wine per day.

\section{c) Total compensation and the gender gap}

Adding up the cash and in-kind compensation components yields an estimate of total compensation, presented in Figure 3.

Figure 3: Total compensation (real terms, in-kind components at acquisition cost)

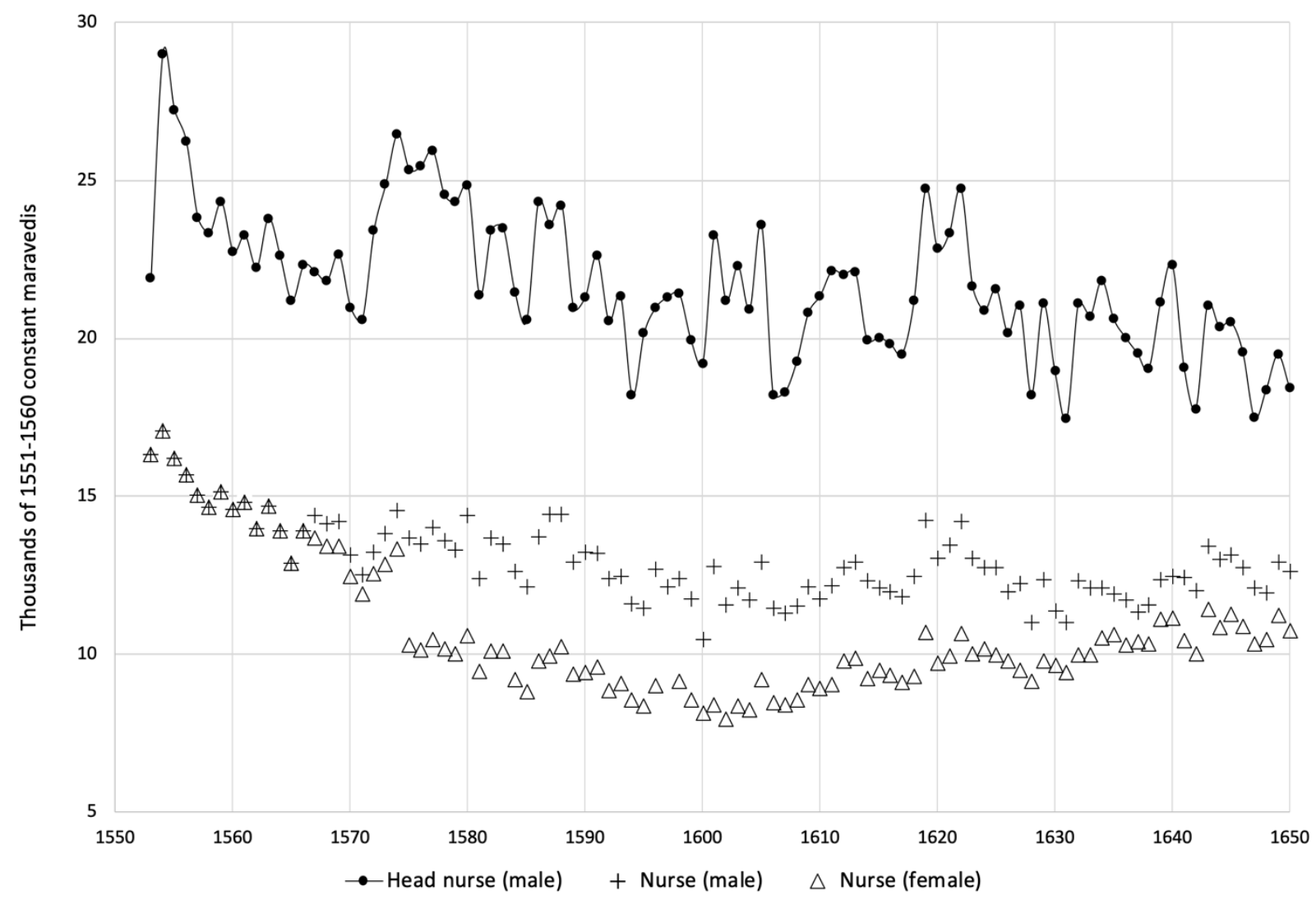

Considering the period $1550-1650$ as a whole, the total compensation of male nurses fell by $26 \%$, while that of female nurses fell by $37 \%$, reflecting the difference in the rations at the end of the period. The head nurse's total compensation also fell by $37 \%$, in this case reflecting the larger initial weight of his cash wages, which depreciated substantially. Since monetary wages 
virtually did not change between 1550 and 1650 , the rapid inflation of the period quickly eroded their value.

With estimates of total compensation in hand, calculating the wage gender gap between male and female nurses is a matter of dividing one series by the other. The result is shown in Figure 4.

Figure 4: The wage gender gap

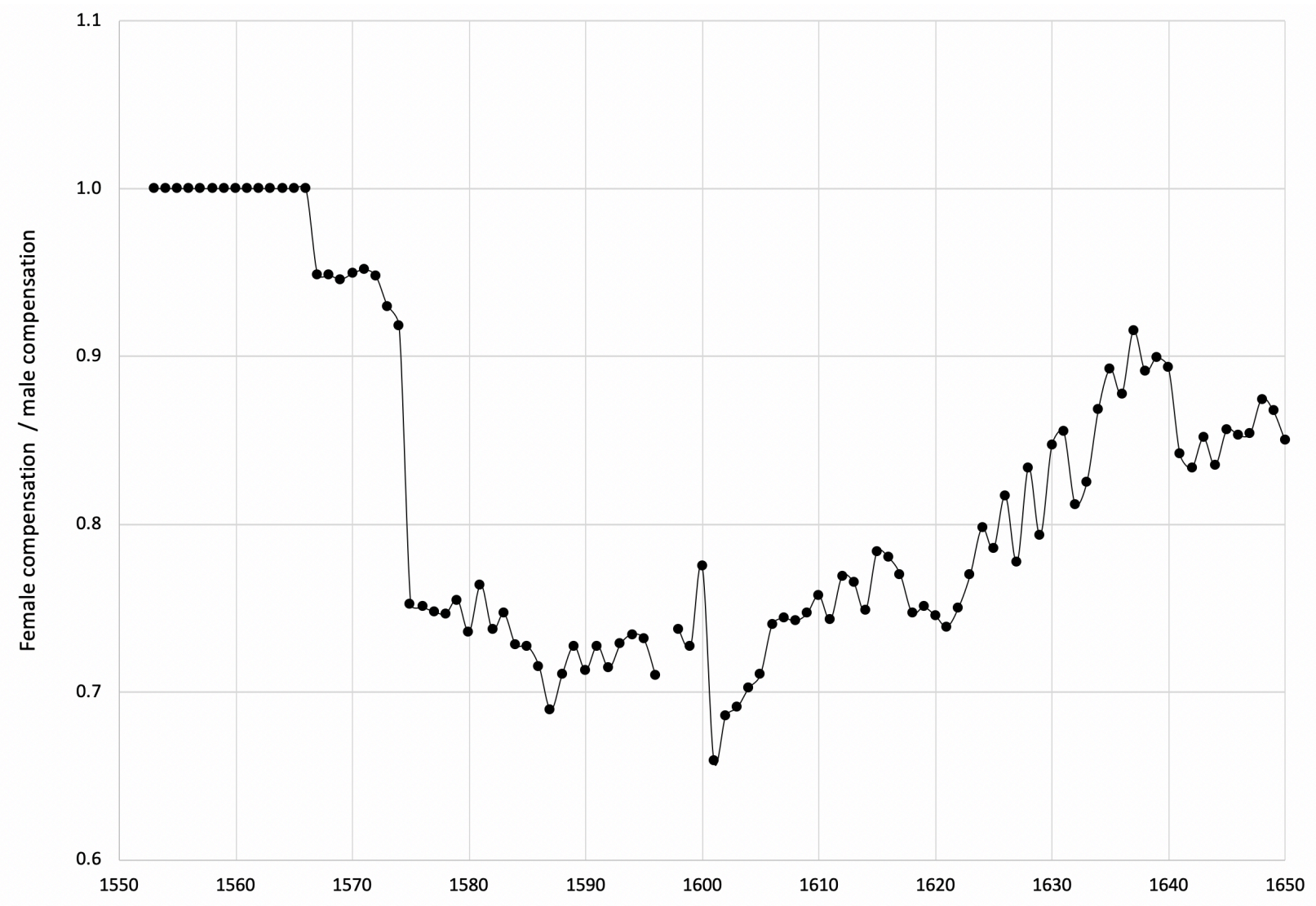

For the first twelve years after the hospital began operations, male and female nurses received identical compensation. The relative position of female nurses deteriorated soon after. First, the men's monetary wages were increased in 1566; next, female wages and rations were both cut in 1575. The ratio between female and male wages hovered between .7 and .75 for almost half a century, before progressively easing up through a series of monetary wage increases for women 
and a decrease in the male bread ration. By the end of our period of analysis, the annual compensation of women had stabilized at around $85 \%$ of male earnings.

\section{Productivity}

The relative productivity of male and female workers is a key input in evaluating the gender wage gap. Given the nature of nursing work, there is a priori no reason to expect productivity differentials by gender. The job descriptions for male and female nurses were identical, and the hospital's bylaws established that the hospital should have one nurse every five or six patients, regardless of gender. ${ }^{34}$

To calculate productivity we need measures of input and output. Since the nurses' job consisted in caring for patients, the ideal output measure is the total number of days female and male patients stayed at the hospital in a year. The hospital admission records provide the names of patients admitted each day, thus making it possible to calculate the total number of admissions per year by gender. ${ }^{35}$ With few exceptions, these records do not provide information on the length of stay. The number of admissions should still be a suitable proxy for nurse workload as long as the duration of patients' stay did not vary much by gender. Zamorano Rodríguez (1997, pp. 219-227) provides data on admissions for seven different years between 1562 and 1600. We added our own patient counts for 1611 (when female nurse salaries were increased for the second time) and 1630.

To calculate the nurses' labor input, we tracked down every salary payment issued to each individual nurse in the years for which we have patient data. We noted the exact number of days for which the employee was being paid, and added them up to calculate the total number of days

\footnotetext{
${ }^{34}$ Zamorano Rodríguez (1997, p. 152).

${ }^{35}$ Archivo Ducal de Medinaceli, Hospital de San Juan Bautista (Tavera), Libros de Recepción de Enfermos.
} 
worked by nurses of each gender in the year. This exercise was only possible in those years for which we could be sure that both payroll records and ordinary account books were complete, thus reflecting every day worked.

Table 2: Patients, days worked, and productivity

\begin{tabular}{|c|c|c|c|c|c|c|}
\hline \multirow[b]{2}{*}{ Year } & \multicolumn{2}{|c|}{ Days worked } & \multicolumn{2}{|c|}{ Patients } & \multicolumn{2}{|c|}{ Nurse days per patient } \\
\hline & Male & Female & Male & Female & Male & Female \\
\hline 1574 & 2114 & 485 & 754 & 154 & 2.80 & 3.15 \\
\hline 1578 & 2260 & 747 & 1024 & 332 & 2.21 & 2.25 \\
\hline 1588 & 1387 & 365 & 482 & 169 & 2.88 & 2.16 \\
\hline 1594 & 1271 & 946 & 543 & 250 & 2.34 & 3.78 \\
\hline 1600 & 1336 & 673 & 562 & 186 & 2.38 & 3.62 \\
\hline 1611 & 1642 & 496 & 726 & 213 & 2.26 & 2.33 \\
\hline 1630 & 1406 & 730 & 694 & 201 & 2.03 & 3.63 \\
\hline
\end{tabular}

Source: days worked calculated from payrolls and ordinary account books for listed years - Archivo Ducal de Medinaceli, Hospital de San Juan Bautista (Tavera), Nóminas; Libros de gasto. Patient numbers for 1574-1600 from Zamorano Rodríguez (1997, pp. 219-227). Patient numbers for 1611 and 1630 collected from hospital admission records - Archivo Ducal de Medinaceli, Hospital de San Juan Bautista (Tavera), Libros de recepción de enfermos.

Table 2 reports days worked and patient numbers for the seven years in our sample that had both complete patient records and employment data. The last two columns show our productivity measure, calculated as the number of days worked by nurses of each gender divided by patient admissions of the same gender -higher numbers imply lower productivity. The high end of the productivity range is essentially the same for men and women (2.03 and 2.16 nurse days per patient respectively). Female productivity is much more variable, though, with three years showing values above 3 nurse days per patient. The lowest productivity level for female nurses is 3.78 nurse days per patient, while male productivity is never lower than 2.88 .

The measured productivity of female nurses was, on average, both lower and more variable than that of their male counterparts. The difference should nonetheless be interpreted with caution, as it is likely the result of an indivisibility situation. Table 2 shows how male patients accounted for $76 \%$ of all admissions in our sample of years, reflecting a well-documented pattern of women 
seeking or receiving a substantially lower amount of medical attention than men in pre-modern times. ${ }^{36}$ As a result, female patient numbers were often too low to support the work of two fulltime female nurses, but too high for one to be sufficient. This resulted in dramatically varying measured productivity figures in response to what could amount to small random variations in the number of patients. For example, in both 1578 and 1630, the hospital employed the equivalent of two full time female nurses throughout the year (747 and 730 days worked respectively). In 1578, there were 332 female patient admissions, which resulted in measured female productivity essentially matching male productivity that year (2.25 vs. 2.21). In 1630, 131 fewer female patients were admitted, pushing the measured productivity of female nurses to 3.63 nurse days per patient, the second worst reading in the sample. Yet, if only one female nurse had been on staff, the value would have been 1.81, a reading exceeding the highest measured productivity in our sample by more than $10 \%$, and possibly quite difficult to achieve while still providing patients with acceptable service.

It is also helpful to illustrate how the much higher numbers of male patients made it easier to manage male staffing levels and maintain a consistent productivity profile. In 1578, the busiest year in our sample, the hospital employed the equivalent of 6.2 full time male nurses, achieving a measured productivity of 2.21 nurse days per patient. If the number of male patients had dropped by 131 (as it did for females in our example above), the productivity of male nurses would have only worsened to 2.53 nurse days per patient (rather than 3.63). But then the hospital could have fired a male nurse, thus increasing the productivity reading to 2.12 nurse days per patient, a level

\footnotetext{
${ }^{36}$ See, for example, Borderías et al. (2010).
} 
that still falls within the observed range. Unlike in the female example, it would have been possible to continue to provide service to patients at the lower staffing levels.

Overall, the data in Table 2 suggest that female nurses were capable of delivering the same levels of output per unit of work than male nurses, something that is observed in three out seven years in the sample. Low and variable numbers of female patients likely resulted in staffing situations that led to lower measured productivity for female nurses in the remaining years.

\section{Discussion}

\section{a) Wage setting}

An oft-repeated motive in the literature is that women's wages in Southern Europe were set customarily, possibly as a fixed percentage of male wages, or that they were ex-gratia payments. De Pleijt and van Zanden argue that Spanish (and other Southern European) female wages in the late middle ages were almost uniformly set by custom at $50 \%$ of male wages. ${ }^{37}$ Lanza García also mentions that women earned half as much as men in construction. ${ }^{38}$ Zamorano Rodríguez, writing precisely about Tavera's hospital, laments the "undervaluation of female work in those times, when women received a monetary amount for their work, not as compensation, but almost as a form of charity." ${ }^{39}$

Our data and analysis speak forcefully against the view that female labor compensation was dictated by custom. The first piece of evidence is our gender gap series. While women were not paid the same as men for most of our period of analysis, they almost always received more than $70 \%$ of male compensation, on occasion achieving parity or getting close to it. More importantly,

\footnotetext{
${ }^{37}$ De Pleijt and Van Zanden (2018, p. 23)

${ }^{38}$ Lanza García (2008, p. 4). In private communication, Ramón Lanza clarified that it is not possible to establish whether women performed the same tasks as men, and that these female wages may correspond to helpers.

${ }^{39}$ Zamorano Rodríguez (1997, p. 169)
} 
there is clear evidence that female wages responded to market forces, as illustrated by the events surrounding the 1611 salary increase. In that year there were three female nurses on staff, working for a monthly cash salary of 10 reales (equivalent to an annual salary of 4,080 maravedis), plus the usual food ration. In August two of them left, and the hospital could not find suitable replacements. The account book documents the successive hiring of two women for 8 reales a month on an emergency basis "to serve as nurses, because no suitable nurse could be found". The second of these, Francisca García, was described as "the daughter of the water carrier" of the hospital, likely no more than a girl. By November 1611, the cash salary of female nurses was raised by $20 \%$. A new employee promptly joined the hospital, followed by another in early 1612. The one nurse from 1611 that had not quit received the same increase, retroactive to September $1^{\text {st }}, 1611$.

While the documentation is less clear on the point, the 1575 reduction in the cash and in-kind compensation of female nurses also appears to be the result of market forces at work. That particular change was part of a large realignment in the compensation of almost all categories of hospital employees, prompted by the adoption of a new set of bylaws in 1569 and the advent of a new patron of the hospital. ${ }^{40}$ While several employees received raises, many others, including the chief physician, the entire chapel staff, the cook, and the female nurses, had their earnings cut within a few years of the bylaw and patronage change. The bread rations of several high-ranking employees were also tightened, with those of the chaplains reduced by up to one third. The salary

\footnotetext{
${ }^{40}$ Unique among Toledo's hospitals, Tavera's was organized as a foundation with lay rather than ecclesiastical patronage. The patron had ultimate say on matters related to the administration of the hospital, and was routinely involved in setting the wages of hospital employees, as attested by multiple inscriptions on the payroll documents. In 1569 the patronage passed on to Guiomar Pardo Tavera, a great-niece of the hospital's founder, though for nearly half a century it was effectively exercised by her mother, Doña Luisa de la Cerda. Thus, the one reduction in female wages in the century under analysis was enacted under the patronage and effective control of two women. See Zamorano Rodríguez (1997, p. 98).
} 
of the single female nurse employed at the hospital at the time of the realignment remained unchanged until her departure in 1575 . Her replacement, however, was hired for a lower cash salary, and her bread ration was $20 \%$ lower as well. The hospital was able to hire female nurses at the same lower compensation rate for the following 23 years, before market pressures forced it to start raising it again.

Female labor markets were almost certainly subject to tighter cultural and institutional constraints than those for male labor, as we discuss more fully below. These strictures, however, did not prevent the laws of supply and demand from operating within the labor market categories that were open to women. While custom may have dictated which markets women had access to, it had little to do with the determination of wages within the markets themselves.

\section{b) Productivity and the gender gap}

Can the lower measured productivity of female nurses explain the observed wage gap? An argument could be made that, because of the indivisibility issue resulting from the low numbers of female patients, the productivity of the marginal female nurse was bound to be lower than that of the marginal male nurse. While this might have held true if Tavera's hospital had been the only employer for nurses, Tavera was only one of many employers. With 27 hospitals in operation and nearly 1,000 beds available in Toledo in the 1570 s, it is unlikely that the specific staffing challenges unique to one hospital's situation could dictate nurses wage levels. ${ }^{41}$ As demonstrated above, market forces were very much in operation in wage-setting, so the particular nurse-to-patient ratio of a single employer likely did not carry much weight.

\footnotetext{
${ }^{41}$ Martz (1983, p. 160)
} 
Matching the measured productivity figures to the changes in wage rates also fails to reveal a consistent pattern. The compensation for female nurses was first cut in 1575. As the wage gap continued to increase, female nurses posted their best productivity readings, matching those of male nurses in 1578 and substantially exceeding them in 1588. In 1600, two years after the first increase in female compensation, female nurses had much worse measured productivity than men. In 1611, when female compensation was still 75\% of male levels, the measured productivity of men and women was almost equal. Overall, there does not seem to be a relationship between measured productivity and compensation changes. It is much more plausible that the baseline productivity of men and women was the same all along, with the variance in measured values reflecting the impact of low and variable female patient numbers.

\section{c) The role of in-kind compensation}

Owing to a lack of necessary information to properly valuate its components, especially lodging, in-kind compensation has been traditionally understudied. Humphries and Weisdorf propose a workaround by assuming that payments in-kind covered subsistence needs (which they interpret as a "respectability" consumption basket). ${ }^{42}$ Such an assumption is not inconsequential; since women have, on average, lower caloric requirements than men, it suggests the construction of the labor contract in a manner that considers a lower compensation level for women as both normal and fair. It also implies dissociating compensation from marginal productivity. While both these conceptions were certainly possible in early modern labor markets, they should not be accepted without evidence.

\footnotetext{
${ }^{42}$ Humphries and Weisdorf (2015, p. 415).
} 
One way of evaluating the Humphries and Weisdorf assumption is to contrast the caloric content of the foodstuffs in in-kind bundles with subsistence caloric requirements. Unfortunately, no anthropometric data are available for sixteenth and seventeenth century Castile. The closest data by gender in the literature are those provided by Humphries for nineteenth century British men and women. ${ }^{43}$ While almost certainly too high for sixteenth century Castilian dwellers, these values will bias the results against our argument, and hence are sufficient for our exercise. ${ }^{44}$ In consideration of the very long shifts worked by nurses and the necessity to move and assist infirm patients, we adopt the caloric requirements for "moderate" work. We use Allen's values for the caloric contents of meat and bread (2500 and $2450 \mathrm{kcal} / \mathrm{kg}$ respectively), and a more conservative figure of $650 \mathrm{kcal} / \mathrm{liter}$ for wine. ${ }^{45}$

Table 3: Caloric content of food rations

\begin{tabular}{|l|c|c|c|c|}
\cline { 2 - 5 } \multicolumn{1}{c|}{} & Period & $\begin{array}{c}\text { Caloric content of } \\
\text { food ration }\end{array}$ & $\begin{array}{c}\text { Daily calorie } \\
\text { requirement }\end{array}$ & Excess calories \\
\hline \multirow{2}{*}{ Male nurses } & $1553-1626$ & 4,633 & 2,894 & 1,739 \\
\cline { 2 - 5 } & $1627-1650$ & 4,070 & 2,894 & 1,176 \\
\hline \multirow{2}{*}{ Female nurses } & $1553-1573$ & 4,633 & 2,550 & 2,083 \\
\cline { 2 - 5 } & $1576-1650$ & 3,737 & 2,550 & 1,187 \\
\hline
\end{tabular}

Source: daily calorie requirement from Humphries (2013, p. 702). Male values are for individuals born in 1850, 23 years of age, height of $172.87 \mathrm{~cm}$, and BMI of 20.73. Female values are for individuals born in 18170-40, 23 years of age, $154.3 \mathrm{~cm}$ of height, and unknown BMI. Caloric content of bread and meat from Allen (2001, p. 421). Caloric content of wine from Mataix-Verdú (2009). Food rations from Table 1.

Table 3 lists the caloric content of the food rations issued to male and female nurses. The analysis is subdivided into two major periods for each gender; the composition of food rations

\footnotetext{
${ }^{43}$ Humphries (2013, p. 702).

${ }^{44}$ García Montero (2014) finds that the average male stature in early $19^{\text {th }}$ century Spain did not exceed $166 \mathrm{~cm}$. Humphries' values are calculated for British men that were, on average, $172 \mathrm{~cm}$ tall. ${ }^{45}$ Allen (2001, p. 421). For wine, Allen uses a value of $850 \mathrm{kcal} / \mathrm{liter}$. This matches the caloric content of modernday red wine with $14 \%$ alcohol content. Early modern unskilled workers were likely served wines with a lower alcohol content; white wine, quite common in early modern Castile, also has a substantially lower caloric value. To err on the side of caution, we adopt an estimate of $650 \mathrm{kcal} / \mathrm{liter}$ based on Mataix-Verdú's (2009) tables for Spanish foodstuffs and averaging the values for red and white wine. We note that, should this estimate be too low, it would bias the results against our argument.
} 
was largely unchanged within each of these periods. ${ }^{46}$ The daily calorie requirements, at 2,894 for men and 2,550 for women, are consistent with virtually any standard of respectability for workers that did not engage in strenuous physical activity. The food rations issued to both men and women amply satisfied those requirements, and provided a substantial amount of "excess" calories, as illustrated in the last column of Table 3. This runs counter to the view that in-kind compensation was only meant to provide subsistence. Even after adopting very conservative estimates of both calorie requirements and the caloric contents of foodstuffs, the nurses of Tavera's hospital had plenty of food left over.

Why were nurses issued such large rations? As illustrated in Figure 5, in-kind compensation accounted for between $70 \%$ and $90 \%$ of total nurse earnings throughout the period. These ration levels were maintained even as the hospital weathered several crises and curtailed other expenses. ${ }^{47}$ By 1650 , with inflation having eroded a substantial part of the value of monetary wages, the value of food and lodging exceeded $80 \%$ of total earnings for all three types of employees.

\footnotetext{
${ }^{46}$ We have used the caloric value of one pound of mutton as part of the female food ration between 1576 and 1650. As discussed above, between 1575 and 1611 female nurses received a cash allowance in lieu of one pound of mutton. Though this allowance was supposed to track the value of the meat, at times it lagged behind. The actual "caloric content" and the excess calories for female nurses might therefore be slightly lower during those years. ${ }^{47}$ Martz (1983, pp. 185-187) reports that, among other cost-saving measures, the meat in meals served to patients was almost halved in 1599, replaced by cheaper protein sources such as eggs. The amount of bread served to patients was similarly reduced in 1619 .
} 
Figure 5: Share of in-kind components in total compensation

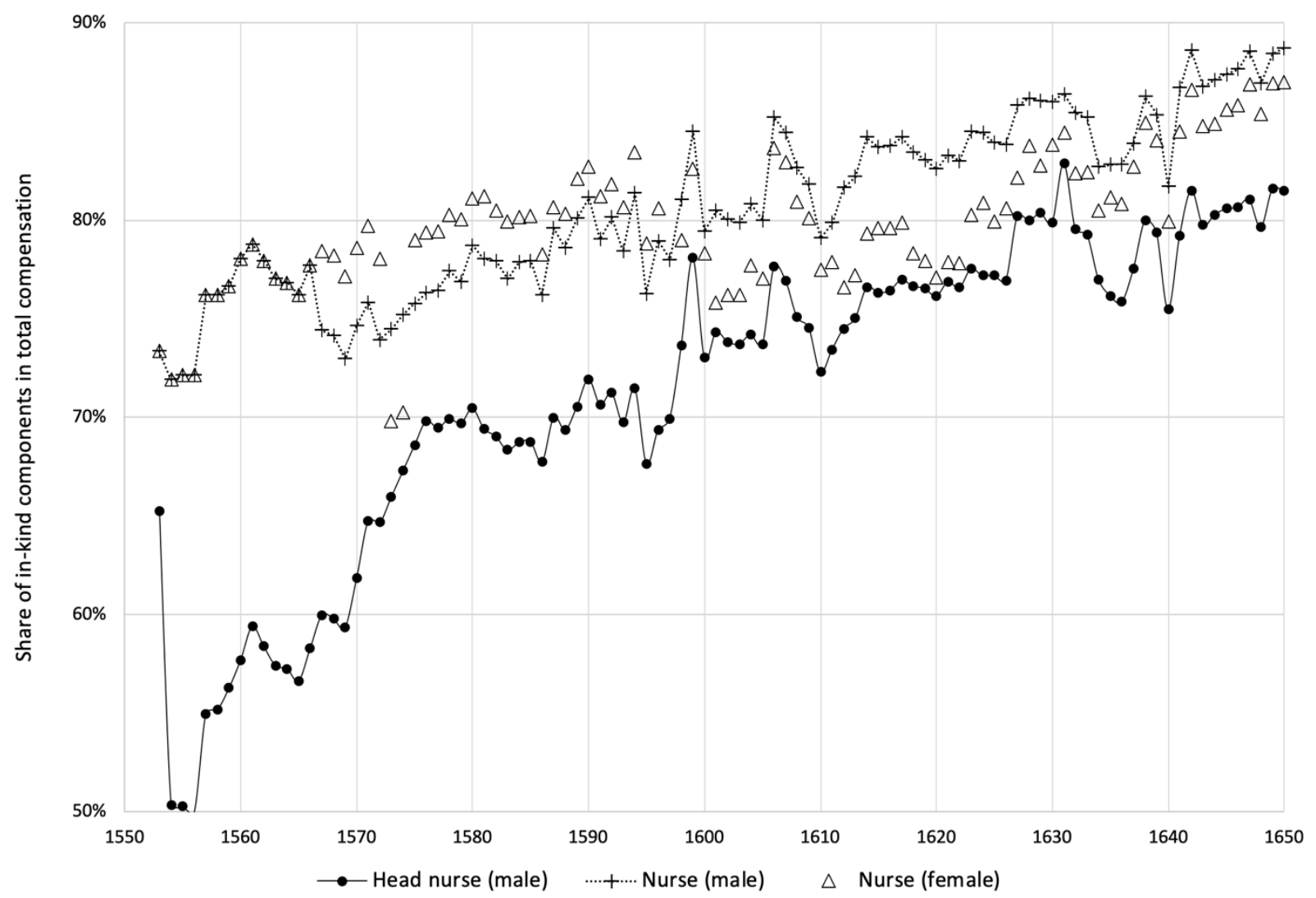

In a time of high price growth a generous food bundle provided a robust inflation-proof compensation package, while also insulating employees from the large year-to-year volatility in the cost of basic foodstuffs. ${ }^{48}$ The food not consumed by employees could be passed on to family members, traded for other foodstuffs, or sold. A second rationale stems from hospitals being funded by a combination of fixed income instruments with invariant nominal yields, as well by as rents often collected in kind. ${ }^{49}$ Labor contracts composed of a rarely changing monetary portion plus an in-kind component matched the hospitals' income profile, and hence reduced financial risk.

\footnotetext{
${ }^{48}$ A similar pattern emerges in the real estate market, where by 1630 upwards of $40 \%$ of rental payments were specified in kind (Drelichman \& González Agudo, 2014). Rental payments in-kind for rural properties also exceeded $30 \%$ of the contract value in the first half of the seventeenth century (González Agudo, 2015).

${ }^{49}$ Martz (1983, p. 192).
} 
c) Occupational crowding, duration of employment, and job separation.

One way in which cultural and institutional constraints on female employment manifest themselves is occupational crowding, the exclusion of women from a large number of professions. The resulting reduction in opportunities for female employment depresses wages in those professions women do have access to, even when wage setting practices are not discriminatory. Occupational crowding is widely documented in several early modern economies, and was likely important in Toledo as well..$^{50}$ The construction examples mentioned above are just one instance of an occupation where women found the doors closed, or were only offered jobs comparable to those of young boys. Women were virtually never employed in skilled occupations.

Data on the duration of nurses' employment can be used to test one implication of occupation crowding. By definition, workers subjected to occupational crowding will have fewer outside options. Standard job ladder models have ambiguous predictions on the impact of outside options on the rate of job separation, but this is mainly because a worker's current employer can increase the wages of individual employees for retention purposes. ${ }^{51}$ This was never the practice in our setting - every nurse employed in a given year was paid the same, and no one threatening to leave was given a retention offer. Without the possibility of wage renegotiation, more outside options result in higher job separation rates, as workers leave their jobs to take advantage of career progress opportunities. If female nurses suffered from occupational crowding, one might expect to observe them holding on to their jobs for longer.

\footnotetext{
${ }^{50}$ Brown (1986, p. 218); Wiesner (1986, p. 202); Van Nederveen Meerkerk (2010, p. 170).

${ }^{51}$ Two key contributions in this literature are Postel-Vinay and Robin (2002) and Cahuc et al. (2006).
} 
The duration of employment (as measured by our data) for male and female nurses was virtually identical. Men held their nursing jobs for an average of 1.71 years, while women did so for 1.78 years. The difference is not significant at any conventional confidence level (two-tailed t-test pvalue $=0.699)$. Male employment length had a standard deviation of 1.74 years, slightly more volatile than female employment, with a standard deviation of 1.5 years. While the difference between the two is significant at the $5 \%$ confidence level ( $\mathrm{F}$ test for two sample variances $\mathrm{p}$ value $=0.03$ ), this is driven by three male nurses with very long tenures. Other than those three outliers, the male and female distributions have no appreciable differences.

That men and women had, on average, the same completed job tenure is not enough evidence to reject the presence of occupational crowding -it merely fails to confirm one of its predictions. There were many other drivers of job separation beyond alternative employment opportunities. The requirement to live at the hospital, for example, meant that nurses had to be almost exclusively single or widowed. Differences in ages of first employment and in age of marriage between men and women may have differentially affected employment duration. On the demand side, variation in patient admission rates by gender would also have influenced rates of job separation, as the hospital hired or fired nurses to meet changing demand levels. We do not observe nurse age nor reason for termination of employment, so any further considerations would be speculative in nature.

\section{Conclusion}

The employment records of the nurses of Tavera's hospital offer a unique laboratory to study female wage determination patterns and the gender wage gap in early modern Castile. We established that male and female nurses performed identical tasks, and were capable of identical productivity levels given adequate patient numbers. Our reconstruction of their compensation 
history, combining detailed data on monetary payments and in-kind rations, shows that female nurses received between $70 \%$ and $100 \%$ of male total earnings.

It is hard to construe the compensation practices of Tavera's hospital as evidence of gender discrimination in wage-setting. While female wages were reduced in 1575 , so were those of several other categories of male employees. Similarly, the in-kind compensation of male nurses was cut in 1627 , at a time when the earnings of female nurses had been rising consistently for several decades. Variations in female compensation levels were dictated by the relative shortage or abundance of female labor, as clearly spelled out in the hospital's account books. The roots of the wage gap must therefore be found in the actual structure of the labor market, as well as other social constraints on female workers (which might be called "pre-market discrimination"). While our data fail to confirm one of the testable implications of occupational crowding, it is almost certain that women faced a more restricted occupational domain than men. The large literacy gap observed between men and women could also have played a role-almost $70 \%$ of the male nurses could sign their name, while none of the women could. Though literacy was not required for nursing work, the difference in skills could have meant that female nurses had lower outside options than male ones, and were hence willing to work for lower wages.

Our results pointedly refute the idea that women's work in early modern Castile was compensated according to old customary practices, or that women were paid a fixed share of male wages. We also show how in-kind compensation was an essential part of the labor contract in high-inflation settings, far exceeding subsistence requirements and, in some periods, accounting for almost $90 \%$ of all earnings. A robust valuation methodology for food and lodging issued as part of payment for services, such as the one employed in this study, seems therefore an essential component of any comprehensive exploration of premodern incomes. 
Quantitative evidence on female labor before the industrial revolution is rare, and scholarly work on the subject if often beset by a lack of comparability with male activities, or by fragmentary data from unrepresentative occupations. Our research opens a new window by studying a line of work in which men and women were expected to perform the exact same tasks and achieve the same outcomes, thus allowing for a clean comparison of their terms of employment. Our results help dispel stereotypes of women workers as subject to customary contracts or recipients of handouts. While gender disparities persisted, their sources are likely to be found in the broader social and cultural environment of the time. 


\section{References}

Allen, R. C. (2001). The Great Divergence in European Prices and Wages from the Middle Ages to the First World War. Explorations in Economic History, 38(4), 411-447.

Allen, R. C. (2013). Poverty Lines in History, Theory, and Current International Practice. Oxford Discussion Paper Series, 683.

Bernardos Sanz, J. L. (1997). No solo de pan. Ganadería, abasteciminto y consumo de carne en Madrid (1450-1805). Ph. D. Dissertation, Universidad Autónoma de Madrid.

Blau, F. D., Ferber, M. A., \& Winkler, A. E. (2014). The Economics of Women, Men, and Work (7th edition). Upper Saddle River, NY: Prentice-Hall.

Borderías, C., Pérez-Fuentes, P., \& Sarasúa, C. (2010). Gender Inequalities in Family Consumption: Spain 1850-1930. In T. Addabbo, M. P. Arrizabalaga, C. Borderías, \& A. Owens (Eds.), Gender Inequalities, Households and the Production of Well-being in Modern Europe (pp. 179-195). Farnham: Ashgate.

Brown, J. C. (1986). A woman's place was in the home: woman's work in renaissance Tuscany. In M. W. Ferguson, N. J. Vickers, \& M. Quilligan (Eds.), Rewriting the Renaissance: the discourses of sexual difference in early modern Europe (pp. 206-224). Chicago: University of Chicago Press.

Burnette, J. (1997). An investigation of the female-male wage gap during the industrialr evolution in Britain. Economic History Review, 50(2), 257-281.

Burnette, J. (2008). Gender, Work and Wages in Industrial Revolution Britain. Cambridge: Cambridge University Press.

Cahuc, P., Postel-Vinay, F., \& Robin, J.-M. (2006). Wage bargaining with on-the-job earch: theory and evidence. Econometrica, 74(2), 323-364.

Carasa Soto, P. (1983). Introducción. In Censo de Ensenada 1756. Madrid: Centro de Gestión Catastral y Cooperación Tributaria, Tabapress.

Carrobles Santos, J., Izquierdo Benito, R., Martínez Gil, F., Rodríguez de Gracia, H., \& Del Cerro Malagón, R. (1997). Historia de Toledo. Toledo: Editorial Azacanes - Librería Universitaria de Toledo.

Castro, C. de. (1987). El pan de Madrid. El abasto de las ciudades españolas del Antiguo Régimen. Madrid: Alianza.

De Pleijt, A., \& Van Zanden, J. L. (2018). Two Worlds of Female Labour: Gender Wage Inequality in Western Europe, 1300-1800. EHES Working Paper 138.

Drelichman, M., \& González Agudo, D. (2014). Housing and the Cost of Living in Early Modern Toledo. Explorations in Economic History, 54(1), 27-47.

Feliú, G. (1991). Precios y salarios en la Cataluña moderna (Vol. 2). In Estudios de Historia Económica: Vol. 22 (Vol. 2). Madrid: Banco de España.

García Montero, H. (2014). Estatura y niveles de vida en la España interior, 1765-1840. Ph.D. Dissertation, Universidad Complutense de Madrid. 
Gary, K. (2017). Constructing equality? Women's wages for physical labor, 1550-1759. Lund Papers in Economic History. No. 158.

Gibson, A. J. S., \& Smout, T. C. (1995). Prices, Food, and Wages in Scotland 1550-1780. Cambridge: Cambridge University Press.

Goldin, C. (1990). Understanding the Gender Wage Gap: An Economic History of American Women. Oxford: Oxford University Press.

Goldin, C. (2014). A grand gender convergence: its last chapter. American Economic Review, $104,1-30$.

González Agudo, D. (2015). Población, precios y renta de la tierra en Toledo, siglos XVI-XVII. Ph.D. Dissertation, Universidad Complutense de Madrid.

González Agudo, D. (2019). Prices in Toledo (Spain), sixteenth and seventeenth centuries. Social Science History, 43(2).

Hamilton, E. J. (1934). American Treasure and the Price Revolution in Spain, 1501-1650. Cambridge: Harvard University Press.

Hatcher, J., \& Stephenson, J. (Eds.). (2018). Seven Centuries of Unreal Wages. The Unreliable Data, Sources and Methods that have been used for Measuring Standards of Living in the Past. Basingstoke: Palgrave Macmillan.

Horrell, S., \& Oxley, D. (2012). Bringing home the bacon? Regional nutrition, stature, and gender in the ndustrial revolution. Economic History Review, 65(4), 1354-1379.

Humphries, J. (2013). The lure of aggregates and the pitfalls of the patriarchal perspective: a critique of the high wage economy interpretation of the British industrial revolution1. Economic History Review, 66(3), 693-714.

Humphries, J., \& Sarasúa, C. (2012). Off the Record: Reconstructing Women's Labor Force Participation in the European Past. Feminist Economics, 18(4), 39-67.

Humphries, J., \& Weisdorf, J. (2015). The Wages of Women in England, 1260-1850. The Journal of Economic History, 75(2), 405-447.

Lanza García, R. (2008). Producto neto, gasto y crecimiento económico en el antiguo régimen: el caso de Cantabria. Comunicación del IX Congreso AEHE, Murcia.

Lanza García, R., \& Andrés Ucendo, J. I. (2012). El abasto del pan de Madrid en el siglo XVII. Studia Historica, Historia Moderna, 34, 61-97.

López Losa, E., \& Piquero Zaráuz, S. (2018). Spanish Real Wages in the North-western Mirror, 1500-1800. On the Timing and Magnitude of the European Little Divergence. Universidad Del País Vasco Working Paper.

López-Salazar Pérez, J. (1976). Evolución demográfica de La Mancha en el siglo XVII. HIspania, 36, 233-299.

Martín Galán, M. (1985). Nuevos datos sobre un viejo problema: el coeficiente de conversión de vecinos en habitantes. Revista Internacional de Sociología, [Ser. 2], 43(4), 593-633.

Martz, L. (1983). Poverty and Welfare in Habsburg Spain. Cambridge: Cambridge University Press. 
Mataix-Verdú, J. (2009). Tabla de composición de alimentos. Granada: Universidad de Granada, Instituto de Nutrición y Tecnología de Alimentos.

Montemayor, J. (1995). Tolède entre fortune et déclin (1530-1640). Limoges.

Nicholas, S., \& Oxley, D. (1993). The Living Standards of Women during the Industrial Revolution, 1795-1820. Economic History Review, New Series, 46(4), 723-749.

Olivetti, C., \& Petrongolo, B. (2016). The Evolution of Gender Gaps in Industrialized Countries. Annual Review of Economics, 8, 405-434.

Orcástegui Gros, C. (1985). Precios y salarios de la construcción en Zaragoza en 1301. En La España Medieval, 7, 1221-1239.

Pamuk, S. (2001). Prices and Wages in Istanbul, 1469-1914. International Institute of Social History Data File. Retrieved from http://www.iisg.nl/hpw/data.php

Postel-Vinay, F., \& Robin, J.-M. (2002). Equilibrium Wage Dispersion with Worker and Employer Heterogeneity. Econometrica, 70(6), 2295-2350.

Ringrose, D. (1973). The Impact of a New Capital City: Madrid, Toledo, and New Castile, 15601660. The Journal of Economic History, 33(4), 761-791.

Rota, M., \& Weisdorf, J. (2019). Why was the First Industrial Revolution English? Roman Real Wages and the Little Divergence within Europe Reconsidered. Università Di Roma La Sapienza Working Paper.

Sánchez Sánchez, J. (1981). Toledo y la crisis del siglo XVII. El caso de la parroquia de Santiago del Arrabal. Toledo: Caja de ahorro provincial de Toledo.

Sebastián Amarilla, J. A., García Montero, H., Zafra Oteyza, J., \& Bernardos Sanz, J. U. (2008). Del crecimiento a la decepción. La producción agraria en Castilla-La Mancha en la Edad Moderna, una primera aproximación. Comunicación del IX Congreso de la AEHE, Murcia.

Stephenson, J. (2018). 'Real' wages? Contractors, workers, and pay in London building trades, 1650-1800†. Economic History Review, 71(1), 106-132.

Van Nederveen Meerkerk, E. (2010). Market wage or discrimination? The remuneration of male and female wool spinners in the seventeenth-century Dutch Republic. Economic History Review, 63(1), 165-186.

Van Zanden, J. L. (2001). Prices and wages and the cost of living in the western part of the Netherlands, 1450-1800. International Institute of Social History Data File. Retrieved from http://www.iisg.nl/hpw/brenv.php

Van Zanden, J. L. (2009). The skill premium and the "Great Divergence." European Review of Economic History, 13(1), 121-153.

Villaluenga de Gracia, S. (2005). The emergence of double-entry bookkeeping in the church: the journal and the ledgers of the cathedral of Toledo, 1533-1539. Spanish Journal of Accounting History, 3. 
Wiesner, M. E., Ferguson, M. W., Quilligan, M., \& Vickers, N. J. (1986). Spinsters and seamstresses: women in cloth and clothing production. In Rewriting the renaissance: the discourses of sexual difference in early modern Europe (pp. 191-205). Chicago: University of Chicago Press.

Zamorano Rodríguez, M. L. (1997). El hospital de San Juan Bautista de Toledo durante el siglo $X V I$. Toledo: Instituto provincial de investigaciones y estudios toledanos. 


\section{Appendix}

a) Valuation methodology for meals and storehouse rations

The botilleria and the storehouse jointly accounted for bread, wine, mutton, and other food items provided to employees. The botillería always kept the bread accounts; responsibility for the other items resided originally with the storehouse, but shifted to the botilleria over time. Wine accounting passed from the storehouse to the botilleria in 1571. Mutton accounting followed in 1627 for the employees that ate meals in the refectory (which included male nurses) and in 1637 for those that took rations to eat elsewhere (which included female nurses). After this date, the storehouse only accounted for meals served to patients, as well as for occasional items given to employees (mostly candles).

Botilleria books listed the quantities of specific goods to be given to each employee each day. Calculating their annual value is a matter of multiplying by 365 (for nurses were expected to work every day of the year) and selecting a suitable price series. We used the wine and mutton price series from Hamilton (1997, p. 218), themselves sourced from these very same botillería books. We also used the wine price series from González Agudo (2019), obtained from the Toledo City Hall, as a measure closer to market (rather than wholesale) prices. The bread price calculation is discussed in the next section of this appendix.

Storehouse books recorded the value of the meals and rations handed out each day (exclusive of items accounted for by the botilleria). Because the price of foodstuffs varied seasonally, estimating the annual value of a storehouse ration required collecting several observations throughout the year. Given the amount of documentation involved, we sampled storehouse books every five years. Additionally, we made sure to sample the years in which the quantity of food included in storehouse rations changed. For the years before 1600, we recorded the value of each 
employee's ration on the first day of each month, and then calculated an annual average. For the period after 1600, when the value of the storehouse rations had decreased somewhat, we increased the sampling interval to two months. This yielded estimates of the annual value of the food rations for each type of employee at five year intervals between 1553 and 1627 . We then interpolated values linearly to fill in the unsampled years.

Estimating the value of the head nurses' ration required an additional step. The head nurse was seated at the chaplain's table, and shared in the bread, wine, starters, and desserts. The storehouse books disaggregate the value of some of these items per employee, while giving a global amount for others (which ones are disaggregated and which are listed globally varies over time). In order to calculate the value of the head nurse's ration on each day we sampled, we first added up the value of the items assigned to him specifically. We then added the value of the items served "for the table", divided by the number of people listed as attending the chaplains' dinner.

\section{b) Bread prices}

Tavera's hospital did not bake its own bread; it rather obtained the necessary wheat, and then contracted out the entire process of turning it into table bread to local bakeries. The hospital received some wheat as rent payment for properties it owned, and purchased the remainder on the market in several large transactions per year. These purchases, meticulously recorded in the wheat accounts of the botillería books, were the basis for Hamilton's (1934) wheat price series, on which we also rely. Wheat was delivered to several bakeries, which were responsible for all aspects of the bread-making process, from milling the grain to delivering the final product. Contracts existed for both candeal (high quality) bread, reserved for the top management, and 
common bread. ${ }^{52}$ We focus on the latter, which was served to the rank and file employees, as well as patients, and is representative of the bread consumed by the working classes.

Once they received the wheat, the bakeries would keep part of it as payment for their services and tax obligations, and process the remainder into standard one pound loaves. All transactions detailing the number of fanegas of wheat delivered and the number of pounds of bread received in exchange are recorded in the bread accounts of the botilleria books throughout the year, allowing us to calculate an annual weighted average of the bread / wheat ratio. Multiplying it by the price paid for wheat and dividing by the number of pounds received gives a straightforward measure of the wholesale price of a pound of bread. For the years 1535-46 we obtained similar data from the Hospital del Nuncio, while the 1573, 1574, and 1588 data points are from the Colegio de Infantes. ${ }^{53}$ Their ratios correspond quite closely to those of Tavera's hospital in neighboring dates.

\footnotetext{
${ }^{52}$ Common bread is the lowest quality of bread present in our sources. López Losa and Piquero Zaráuz (2018, p. 18) document the appearance of a brown bread of even lower quality, pan de cabezuela, in early seventeenth century Madrid. Very little rye was produced in Castile, and there is no evidence whatsoever of rye bread in the literature (Sebastián Amarilla, García Montero, Zafra Oteyza, \& Bernardos Sanz, 2008).

${ }^{53}$ Data from 1535-46 are from Archivo y Biblioteca Capitulares de Toledo, Hospital del Nuncio, 540. Data for 1573-74 and 1588 are from Archivo y Biblioteca Capitulares de Toledo, Obra y Fábrica, Colegio de Infantes, 233, $238,250$.
} 
Figure A.1: Pounds of bread per fanegas of wheat

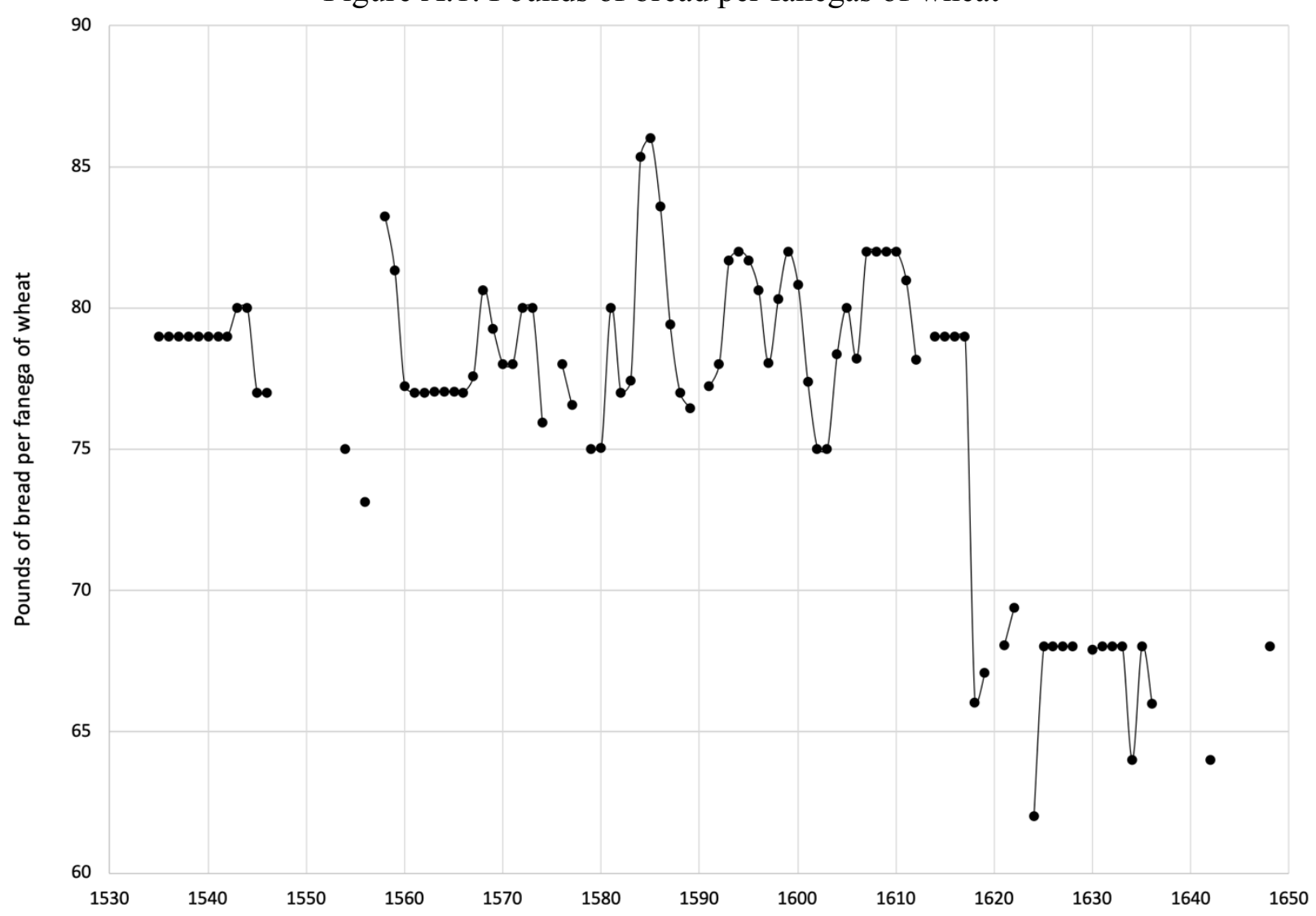

Figure A.1 shows the average annual ratio between pounds of bread and fanegas of wheat delivered to the bakeries. López Losa and Piquero Zaráuz (2018, p. 19) estimate the physical yield of one fanega of wheat at 87.13 pounds of common bread, which puts the bakeries average gross margin at $9.4 \%$ before 1618 , and at $23.1 \%$ thereafter. Such a steep drop is almost certainly related to institutional reasons, possibly a local tax on either milling or baking (since wheat was delivered by the hospital to the bakeries, it cannot be related to the grain market). The Crown considered taxing milling at the beginning of the seventeenth centuries, but the idea was abandoned on fears that it would result in higher bread prices (Lanza García \& Andrés Ucendo, 2012). Municipalities, however, could have levied their own taxes, and had reason to do so. Toledo was comprised in the area subject to pan de registro requirements to supply Madrid, the 
growing capital, with bread at subsidized rates (Castro, 1987; Bernardos Sanz, 1997). Those requirements may have been met by taxing wheat at mills and bakeries.

Exogenous factors such as the one that prompted the discrete jump in 1618 are problematic for the Allen (2001) methodology, which consists of performing regressions of eighteenth and nineteenth century bread prices on wheat prices, masons' wages, and city fixed effects, and retrocasting prices using the estimated coefficients. This technique can yield plausible estimates for retail bread prices in the absence of changes in unobservables. Intra-period variations in the institutional environment or other unaccounted for determinant of bread prices, however, can lead to biased estimates.

Figure A2: Comparison of Allen's bread price estimates and Toledo's wholesale cost

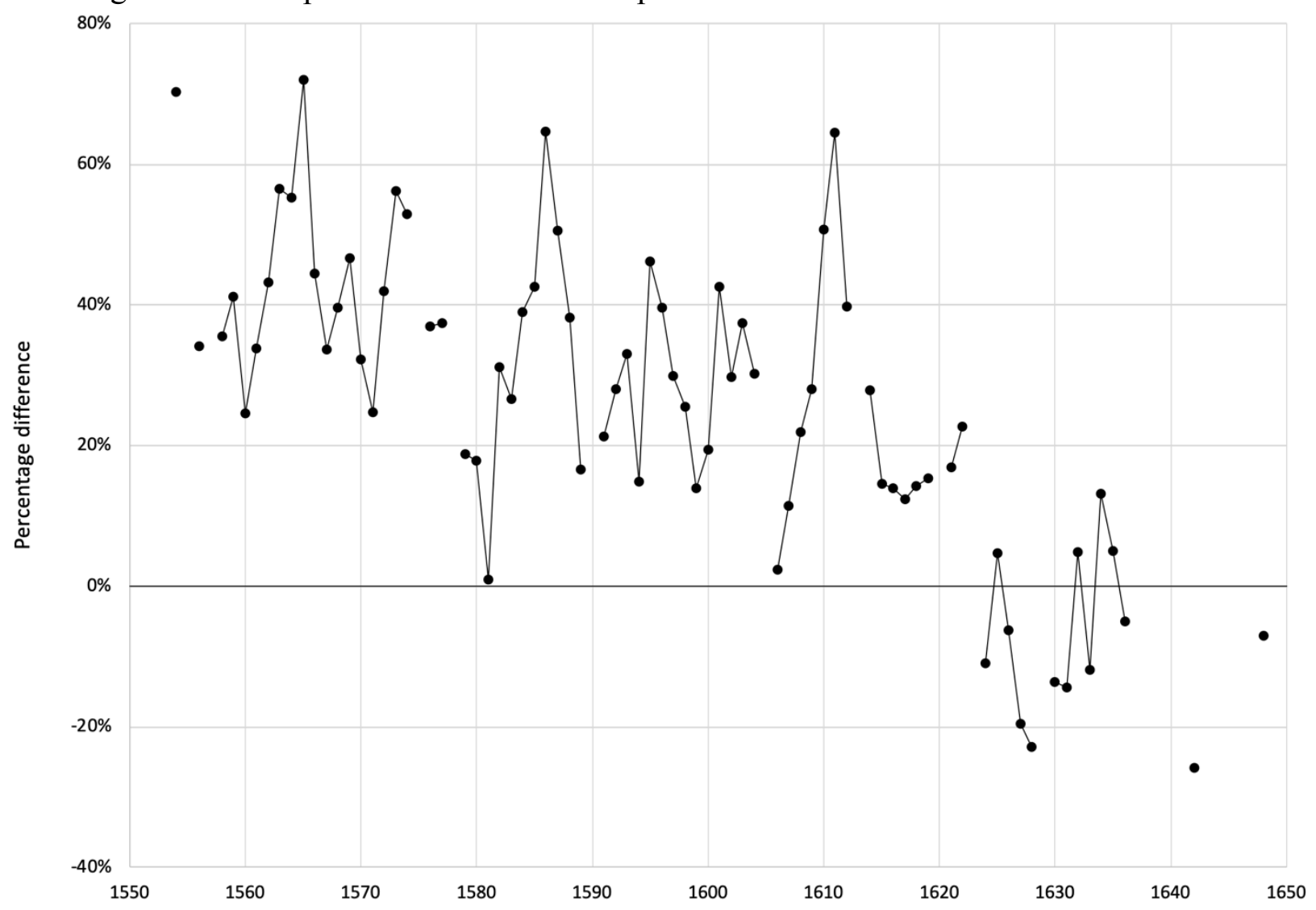


Allen used Hamilton's "New Castile" price and wage data to estimate his "Madrid" bread price series. Since the price data are actually from Tavera's botillería books, his estimates are for Toledo, not Madrid, and wholly comparable to ours. Figure A.2 shows the percentage difference between Allen's bread price estimates and our wholesale cost. Until 1617, Allen's series is on average $34 \%$ higher than ours, not an unreasonable margin between retail and wholesale prices. From 1618 onwards, however, Allen's retail price estimates are lower than the hospital's wholesale cost of bread. This implausible situation is the result of the 1618 institutional change, which cannot be accounted for with a time-invariant city fixed effect. Similarly, rules of thumb based on the price of wheat, such as the one used by López Losa and Piquero Zaráuz (2018), will also prove inadequate if the fiscal change affected the milling or baking of bread, rather than the market for grain.

\section{c) Valuating in-kind compensation at retail prices}

As discussed above, while Allen's estimates of bread prices suffer from the inability to account for structural breaks, at least until 1618 they are probably an acceptable approximation to retail bread prices. Similarly, González Agudo’s (2019) wine price series, though affected by significant gaps that have been filled with Hamilton's data, is likely a usable approximation to retail values. Though we do not have mutton retail prices, using these two alternative sources to valuate in-kind compensation can still nudge the estimates in the direction of what employees could have expected to pay had they wished to purchase the same bundles on the street. 


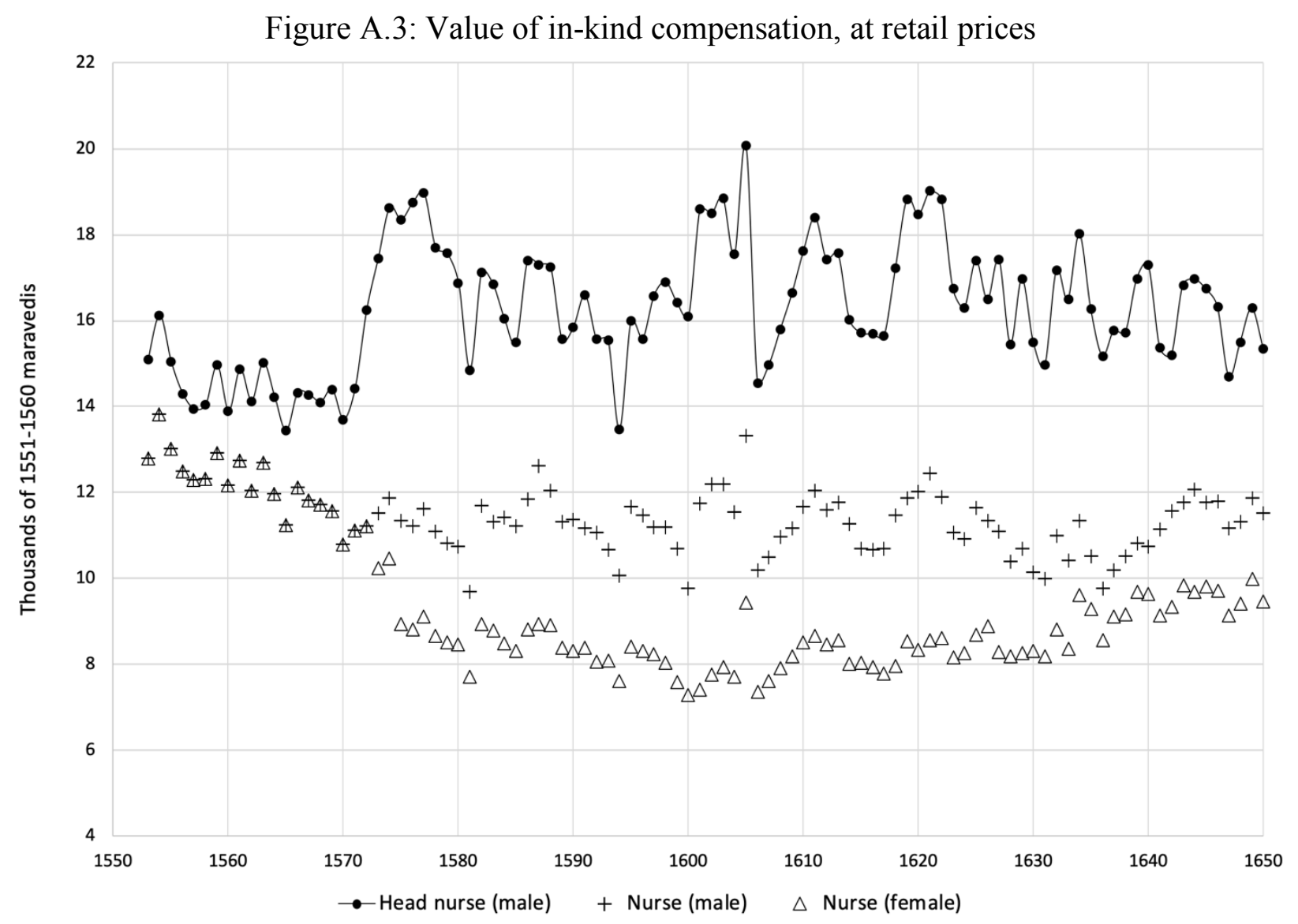

Relative to the estimates at acquisition cost presented in Figure 2, the values in figure A.3 are higher and more volatile, reinforcing the notion that in-kind compensation served to insulate employees from the effects of large fluctuations in the price of basic foodstuffs.

\section{d) The role of the head nurse}

The hospital bylaws (constituciones) provide for the hiring of a male and a female head nurse.

Based on them, Zamorano Rodríguez (1997, pp. 27, 127-129) describes the head male nurse and the head female nurse as being on equal footing and sharing the same responsibilities. Our analysis of the payroll, expenditure, and storehouse records is at odds with this assessment. The payroll records only list a head female nurse in 1552-1554 and 1573-74. In those years, the salary of the head female nurse was the same as that of regular female nurses between 1555 and 
1572. On the five specific years when a head female nurse was present, there were no employees listed as regular nurses, so the task of tending to the female patients would have been discharged by the "head" nurse. Additionally, the (male) head nurse post was often filled by a chaplain, who could conveniently administer the sacraments himself, something that women, unable to be ordained as clergy, could never do. Regular male nurses were designated as "minor nurses" in order to differentiate them from the head nurse, while the same distinction is only very occasionally made for women. We conclude that, despite the formal distinction drawn in the bylaws, there were no actual differences between the position of head female nurse and regular female nurses. 